\title{
STUDY OF INFLUENCE OF STORE ENVIRONMENT ON IMPULSE BUYING TENDENCY
}

\author{
Naratama I Made*, Rahyuda I Ketut \\ Postgraduate Program, University of Udayana, Bali, Indonesia \\ *E-mail: detanaratama@gmail.com
}

\begin{abstract}
The results of this study find the store environment has a positive and significant effect on the urge to buy impulsively and impulse buying. This means that the application of a good store environment and the urge to buy high impulsively will trigger impulse buying in fashion products. The results of impulse buying tendency have a positive and significant effect on urge to buy impulsively and impulse buying. This means that the tendency of consumers towards fashion products will increase by being followed by insistence on themselves so that impulse buying of fashion products will occur. Urge to buy impulsively is a mediating variable that influences store environment and impulse buying tendency with impulse buying. Practical implications that can be given from the findings of this study is the application of a good store environment can be a factor that supports the occurrence of impulse buying. Impulse buying tendency is the tendency of consumers towards an object (fashion products) so that when consumers visit a mall that has a diversity of fashion products, consumers will feel a strong urge to impulse buying. Urge to buy impulsively is an insistence, so with the discount, consumers will become buyers impulse. Practical implications that can be given from the findings of this study are the application of the store environment through structuring the layout, the use of room temperature, the selection of the right music, is expected to encourage impulse buying in fashion products at Mal Bali Galeria, apart from external consumer factors, internal factors of consumers can creating urge to buy high impulsively for fashion products.
\end{abstract}

\section{KEY WORDS}

Store environment, impulse buying tendency, urge to buy impulsively, impulse buying.

People, who have a consumptive lifestyle, tend to choose to go to department stores or malls on holidays or in their spare time, of course through consideration of the convenience and convenience that will be obtained at shopping centers or malls (Herawati et al., 2013). The business opportunity is an opportunity for business people in various fashion industries, so marketing fashion products in shopping centers is quite a chance to bring up unplanned buying behavior for consumers. Dyatmika and Sudiksa (2015) stated that the potential in the retail sector must be studied and studied for business people in the retail field, towards the unique character of each consumer. The unique character in this case is the behavior of consumers who have their own characteristics compared to most other consumers. Most consumers have unplanned characters. They usually like to act on "last minute", if they shop, they often become impulse buyers (Susanta, 2007). Unplanned purchases are unique and continuous lifestyles by individuals (Saad and Metawie, 2015). Consumers who have an impulse attitude tend to come from social circles who are very concerned about social status and image, this is done in order to get attention in their social class environment (Seetha and Suganya, 2017). Rook (1987) states that impulse buying generally occurs due to the arrival of strong motivation that changes to the desire to buy a particular commodity. According to Utami (2010: 51) impulse buying is a purchase that occurs when consumers see a particular product or brand, then consumers become interested in getting it, usually because of an interesting stimulus from the shopping environment (mall).

Research proposed by Baker et al. (2002), Foroughi et al. (2013) factors from the store environment, namely ambient, design, and social, will bring more pressure on consumers, this is because ambient factors are the atmosphere as a basic characteristic of an unreal condition which tends to affect the nonvisual senses, which include temperature, sound, 
smell and lighting, while the design factors are environmental components that tend to be seen and more real that adorn the store so that the store looks more attractive. Design factors can include color, facilities, merchandising arrangements, layout settings. Social factors are people (consumers and employees) who are in a store environment and interact with each other (Nuzula and Wusko, 2014). These three factors together form the insistence on the consumer, besides the store environment factor, the consumer's personality factor has an important role.

The tendency is an attitude that implies a person's desire for a product or service, this is what encourages impulse buying behavior that arises from each individual. This focus is based on the personality of the consumer, not on the external environment of an individual (Maymand and Ahmadinejad, 2011). Mohan et al. (2013), states impulse buying tendency is a spontaneity in purchasing activities without prior planning, with little or no consideration of the consequences that might be received. A higher impulse buying tendency can trigger pressure on impulse buying behavior. Omar et al. (2001) states that impulse buying tendency of an individual is conceptualized as a characteristic possessed by consumers, therefore impulse buying tendency can be defined as a uni-dimensional construction that embodies the tendency of consumers to think and shop in ways that are recognizable and different. Seetha and Suganya (2017) explains that impulse buying tendency can be attributed to personality traits that trigger a person to impulse buying habits, indirectly the tendency can trigger more pressure on impulse buying behavior.

Mohan et al. (2013) states that urge to buy impulsively is a feeling experienced when seeing or meeting an object in a store environment like a particular product. Muruganatham and Bhakat (2013) in their research found the availability of exclusivity of certain products, a clean atmosphere, wide format, and anonymity are a number of reasons to increase urge to buy impulsively at airport retail outlets. Research conducted by Badgaiyan and Verma (2015) states that there are three reasons regarding the relationship between urge to buy impulsively with impulse buying, namely, first, there are still many indicators that can influence these variables simultaneously, both economic variables that have an impact on consumers' impulse buying behavior are still lacking a lot of review, the third most of the research related to impulse buying is only done in western countries, while in countries in Asia it is still lacking attention. Verplanken and Herabadi (2001) state that affective aspects include emotional urges that simultaneously include feelings of pleasure and joy after buying without planning. Badgaiyan and Verma (2015), explained that urge to buy impulsively with impulse buying behavior has a positive relationship. Suprapti (2010: 50) also states that pressure will generally precede actual behavior.

\section{LITERATURE REVIEW}

Thurstone, defines attitude as "affection or feeling for a stimulus", this states that the attitude has a relationship with feelings not with trust, because trust is a cognitive aspect of an object, then attitude is a feeling or affective response that has about an object ( Thurstone in Sunarto 2003: 160). Attitudes are expressions of one's feelings that reflect their likes or dislikes about objects. Because one's attitude is the result of a psychological process, it cannot be observed directly but must be inferred from what is said or done (Suprapti. 2010: 135). Judging from the structure, attitude consists of three components, namely the cognitive component, the affective component, and the conative component. The cognitive component in the form of one's beliefs, the affective component involves the emotional aspect, and the conative component is an aspect of the tendency to act in accordance with the attitude. The affective or emotional aspects are usually rooted most deeply as a component of attitude, which is most resistant to influences that might change attitudes (Zuchdi, 1995).

According to Japarianto and Sugiharto (2011) classifies unplanned buying behavior as follows:

- Planned impulse buying. Unplanned purchases made by consumers without any certainty of buying what products but have planned to shop when leaving for the store. 
- Reminder impulse buying. Spontaneous purchases made by consumers when they remember to purchase the product. It can be assumed that before the consumer had made a purchase and decided to make a repurchase.

- Suggestion impulse buying. Purchases are made when the consumer sees the product, sees the usage procedure or benefits and decides to make a purchase.

- Pure impulse buying. Impulse buying is done by consumers due to emotional outbursts so that they purchase products or goods outside of their buying habits so that this is purely derived from the internal conditions of consumers.

Urge to buy impulsively is a feeling of feeling that is experienced by someone suddenly and spontaneously to immediately buy the desired product. However, needs or desires, although often strong, are sometimes unbearable, but are not always done (Rook and Fisher, 1995: 305). According to Beatty and Ferrel (1998: 172) it seems reasonable to consider decisions and behavior separately. Urge to buy impulsively is the desire of past experience in dealing with an object in a particular environment. Consumers can feel the urge to do impulse buying behavior when seeing or meeting some things such as promotional programs of a product (Muruganantham and Bhakat, 2013). Xu (2007) states that the store environment will also affect consumers to the insistence in their series to make purchases that are not planned beforehand so that consumers will take the actual action of impulse buying.

Impulse Buying Tendency is defined as the extent to which an individual is likely to make an unwanted, immediate, and unthinkable purchase (Maymand and Ahmadinejad, 2011). Rook (1987) states that there are several psychological motivations from each individual to do impulse buying felt when shopping. Direct visual exposure or promotional actions will increase the individual's tendency to impulse buying, but sometimes without a reason or a clear stimulus, the individual may be motivated to impulse buying. The tendency to impulse buying has been conceptualized as the characteristics of each individual (Park and Lennon, 2006) that affect self-response to environmental stimuli.

Three types of store environment signals were studied in the study of Baker et al. (2002): ambient, design, and social. Ambient signals refer to store background characteristics, such as temperature, lighting, noise, music, and aroma. Design cues include stimuli that are at the forefront of consumer awareness, such as architecture, color, and materials. Social cues refer to conditions related to the number, type, and behavior of consumers and employees, and the same characteristics (Bitner, 1992). In addition, the level of density and the number of visitors as a reflection of the three aspects can also influence the consumer's desire to impulse buying (Xu, 2007). Donovan et al. (1994) and Mohan et al. (2013) show that the store atmosphere gives pleasure, so consumers will spend more time and money as well that a good layout reduces the "level of information", ie a good layout helps consumers find products and information easily, unlike if the layout a complicated shop. Suwantari and Ardani (2014) argue that, visitors to a store are not positively influenced by store lay-outs, but many negative effects will arise if the placement of lay-out is wrong, such as placing a counter inside a store that causes the visitor's space to be blocked.

Hypothesis:

- H1: Store environment has a positive and significant effect on urge to buy impulsively;

- H2: Impulse buying tendency has a positive and significant effect on urge to buy impulsively;

- H3: urge to buy impulsively has a positive and significant effect on impulse buying;

- H4: Store environment has a positive and significant effect on impulse buying;

- H5: Impulse buying tendency has a positive and significant effect on impulse buying;

- H6: Urge to buy impulsively can mediate significantly the influence of store environment with impulse buying;

- H7: Urge to buy impulsively can mediate significantly the effect of impulse buying tendency with impulse buying. 


\section{METHODS OF RESEARCH}

This research took place in a large mall in Badung Regency namely Mal Bali Galeria. This consideration is used because the mall has a shopping center such as department stores and Hypermart, and has a unique mall environment concept and complete facilities available, so consumers feel comfortable and want to spend time at the mall. Various types of outlets are available, it is expected to be able to meet the desires of consumers so that the tendency to impulse buying will also be greater. Although located in Badung Regency, visitors to the mall to be studied are not only from Badung Regency but also from other regions as long as the visitor meets the requirements as a respondent.This study uses data analysis techniques for Structural Equation Modeling (SEM). The use of the SEM method will be able to display a comprehensive model and can explain the relationship between variables with one another according to Gunadhi (2012).

\section{RESULTS AND DISCUSSION}

Impulsively as a mediating variable that influences store environment and impulse buying tendency towards impulse buying. The effect size criteria according to Cohen in Becker (2002) is $0.02-0.15$ (weak impact), $0.15-0.35$ (moderate impact), and $>0.35$ (strong impact). VAF calculations can use the following formula: $\operatorname{VAF}=\left(a^{*} b\right) /\left(a{ }^{*} b+c\right)$, where $a=$ the magnitude of the effect of exogenous variables on endogenous variables; $b=$ the magnitude of the influence of the mediator variable on the endogenous variable; $c=$ the amount of direct influence of exogenous variables on endogenous variables.

Based on Table 1, it can be seen that the store environment variable has a direct effect on impulsively urge to buy variable at 24.6 percent, impulse buying tendency variable has a direct influence on impulsively variable urge to buy of 24.2 percent, variable urge to buy impulsively have a direct influence on impulse buying variables of 20.1 percent, store environment variables have a direct influence on impulse buying without going through impulsively to buy at 56.2 percent and impulse buying tendency variable has a direct influence on impulse buying without through urge to buy impulsively at 41.2 percent.

Table 1 -Standardized Direct, Indirect, Total Effect, VAF

\begin{tabular}{llll}
\hline & Direct Effect & Indirect Effect & Total Effect \\
\hline Store environment > Urge to buy impulsively & 0,246 & - & 0,246 \\
\hline Impulse buying tendency > Urge to buy impulsively & 0,242 & - & 0,242 \\
\hline Urge to buy impulsively > Impulse buying & 0,201 & - & 0,201 \\
\hline Store environment > Impulse buying & 0,562 & 0.049 & 0,611 \\
\hline Impulse buying tendency > Impulse buying & 0,412 & 0,049 & 0,461 \\
\hline VAF & & \\
\hline Store Environment $\rightarrow$ Urge to Buy Impulsively $\rightarrow$ Impulse Buying: & \\
$(0,246 * 0,201) /(0,246 * 0,201+0,562)=0,08$ (weak impact) & & \\
\hline Impulse Buying Tendency $\rightarrow$ Urge to Buy Impulsively $\rightarrow$ Impulse Buying : & & \\
$(0,242 * 0,201) /(0,242 * 0,201+0,412)=0,10$ (weak impact) & & \\
\hline
\end{tabular}

Primary Data, 2018.

In addition to direct influence, there is an indirect effect between store environment variables on impulse buying variables mediated by urge to buy impulsively and impulse buying tendency variable to impulse buying variable mediated by variable urge to buy impulsively. Store environment variables have an indirect effect on impulse buying variables through a variable urge to buy impulsively at 4.9 percent. Then the impulse variable buying tendency has an indirect effect on the impulse buying variable through the urge to buy impulsively variable of 4.9 percent. This shows that the influence of the variable store environment and impulse buying tendency on the variable impulse buying will increase if mediated by the variable urge to buy impulsively. Besides there are direct and indirect effects between variables in this study, there is also a total effect that shows the number of influences from various relationships. Total influence is the addition of direct and indirect 
influences. The variable urge to buy impulsively as an intermediate variable increases the influence of store environment on impulse buying by 4.9 percent, so the total effect becomes 61.1 percent and the remaining 38.9 percent is explained by other variables. Similarly, the urge variable to buy impulsively as an intermediate variable increases the influence of impulse buying tendency on impulse buying by 4.9 percent, so that the total effect becomes 46.1 percent and the remaining 53.9 percent is explained by other variables.

Table 1 shows the results of the calculation of VAF urge to buy impulsively as a mediating variable the effect of store environment on impulse buying shows a value of 0.08 (8 percent) which means a weak impact. VAF urge calculation results to buy impulsively as a mediating variable impulse buying tendency towards impulse buying shows a value of 0.10 (10 percent) which means a weak impact.

Table 2 - Regression Weights Estimation

\begin{tabular}{llll}
\hline Direct Effect & Estimate Standardized & p-value & Discription \\
\hline Store Environment $\rightarrow$ Urge to Buy Impulsively & 0,246 & 0,031 & Sig. \\
\hline Impulse Buying Tendency $\rightarrow$ Urge to Buy Impulsively & 0,242 & 0,044 & Sig. \\
\hline Urge to Buy Impulsively $\rightarrow$ Impulse Buying & 0,201 & 0,020 & Sig. \\
\hline Store Environment $\rightarrow$ Impulse Buying & 0,562 & 0,000 & Sig. \\
\hline Impulse Buying Tendency $\rightarrow$ Impulse Buying & 0,412 & 0,000 & Sig. \\
\hline Store Environment $\rightarrow$ Urge to Buy Impulsively $\rightarrow$ Impulse Buying & 0,049 & - & - \\
\hline Impulse Buying Tendency $\rightarrow$ Urge to Buy Impulsively $\rightarrow$ Impulse Buying & 0,049 & - & - \\
\hline
\end{tabular}

Primary Data, 2018.

From the Regression Weights estimation output in Table 2, the results of the hypothesis proposed are as follows.

Hypothesis 1 which states that the store environment has a positive and significant effect on urge to buy is impulsively accepted with a coefficient of 0.246 and a probability value of 0.031 ( $\square 0.05$ ). This result gives the meaning that the better the store environment, the higher the urge to buy impulsively arising from consumers who will impulse buying on fashion products at Mal Bali Galeria. The results of this study are in accordance with the results of previous studies Mattila and Wirtz (2008), Yistiani et al. (2012), and, Putra and Sukawati (2015) show that a pleasant store environment can increase the pressure on purchases. Sellers can guide consumers to explore stores and various products, thus stimulating the desire for impulse buying.

Hypothesis 2 which states impulse buying tendency has a positive and significant effect on the urge to buy impulsively accepted with a coefficient value of 0.242 and a probability value of 0.044 ( $\square 0.05)$. These results mean that the higher the impulse buying tendency of a person, the higher the urge to buy impulsively arising from consumers who will impulse buying on fashion products at Mal Bali Galeria. The results of this study are in accordance with the results of previous studies conducted by Mohan et al. (2013), Maymand and Ahmadinejad (2011), Hanzaee and Taherikia (2010). Impulse buying tendency is conceptualized as the nature of consumers who make purchases spontaneously, as soon as possible, and kinetic, so consumers who have high impulse buying tendency tend to buy more than consumers who experience pressure to impulse buying (Rook and Fisher, 1995) . In this study the tendency is reflected as the consumer's desire for fashion products so that it can be said that the need for fashion products can cause pressure on consumers to impulse buying at Bali Galeria Mall.

Hypothesis 3 which states that urge to buy is impulsively has a positive and significant effect on impulse buying is accepted with a coefficient of 0.201 and a probability value of 0.020 ( $\square 0.05$ ). This result gives the meaning that the higher the urge to buy impulsively someone, the higher the impulse buying of consumers in fashion products at Mal Bali Galeria. Urge to buy impulsively is an urge to do impulse buying which generally will initiate actual impulse behavior. The results of this study are in line with the research conducted by Mohan et al. (2013), and Badgaiyan and Verma (2015). When consumers look at fashion products in a store, they will experience higher pressure so that it can lead to impulse buying (Beatty and Ferrell, 1998), so that consumers cannot resist urge to buy impulsively even 
though they have made their best efforts to control or regulate this desire, this is consistent with research from Baumeister (2002). Other research from (Hanzaee and Taherikia, 2010; Foroughi et al., 2012; Beatty and Ferrell, 1998) states that urge to buy impulsively is positively related to impulse buying behavior.

Hypothesis 4 which states that the store environment has a positive and significant effect on impulse buying is accepted with a coefficient of 0.562 and a probability value of 0.000 ( $\square 0.05$ ). This result gives the meaning that the better the store environment, the higher the impulse buying that arises from consumers in fashion products at Mal Bali Galeria. The results of this study are in accordance with the results of previous studies conducted by Chen (2008), Yuliartini and Sulistyawati (2014), Kazempour and Lotfizadeh (2017) which state that the better the application of the store environment, the tendency to impulse buying will be even greater, from the store environment, namely sales clerks, structuring goods, store arrangements are things that are outside the individual (external factors), and external factors are very influential on the consumer purchasing process (Mangkunegara, 2002: 4). Store environment that is unique (layout, room conditions and lighting) and with a variety of fashion products offered, as well as salespeople who will always help consumers in finding the fashion products they want, consumers are expected to be impulse buying fashion products in the Mall Bali Galeria.

Hypothesis 5 which states impulse buying tendency has a positive and significant effect on impulse buying is accepted with a coefficient value of 0.412 and a probability value of $0.000(\square 0.05)$. These results mean that the higher impulse buying tendency of a person, the higher the impulse buying that occurs in fashion products at Mal Bali Galeria. Each person has a different tendency to do impulse buying. At this point the focus is on internal, not external or environmental surroundings. The tendency experienced by consumers may occur due to the experience that was felt when doing impulse buying before. Maybe consumers feel happy and satisfied with the items purchased; therefore they want to repeat it again. The results of this study are in line with the research conducted by Baumeister (2002), Mohan et al. (2013), and Rook (1987).

Hypothesis 6 which states that urge to buy impulsively has a significant effect on mediating store environment variables to impulse buying is accepted with a value of 0.049 coefficient value. Although it has a significant effect on mediating, Although a positive effect mediates, the role of urge to buy impulsively has a weak impact, because it can directly impact the store environment on impulse buying, but by mediating urge to buy impulsively, the store environment will increase impulse buying. This result means that when consumers are in a comfortable and pleasant shopping environment, there will be a strong urge to impulse buying of fashion products at Mal Bali Galeria. The results of this study are in accordance with the results of research from Badgaiyan and Verma (2015), and Kazempour and Lotfizadeh (2017) explain that store environment promotes impulse buying, namely store environment is an important determinant of impulse buying itself, because the store environment is expected to influence consumer feelings so that there is a strong urge to buy impulsively against a fashion product and cause actual impulse buying (Graa and DanielKebir, 2012).

Hypothesis 7 which states that urge to buy is impulsively influential significantly mediating impulse buying tendency variable on impulse buying is accepted with a coefficient value of 0.049 . Although a positive influence mediates, the role of urge to buy impulsively has a weak impact, because it directly impulse buying tendency can have an impact on impulse buying, but by mediating urge to buy impulsively, impulse buying tendency will increase impulse buying. This means that the tendency of consumers to fashion products will increase when followed by strong pressure from within the consumer, with discounts and offers and with a model that suits consumer desires can increase strong pressure on impulse buying of fashion products at Bali Mall Galeria. The results of this study in accordance with the research of Pranata (2013) states that consumers who have impulse properties will experience a tendency so that they have a greater likelihood of the occurrence of pressure to impulse buying before, because an individual's self reflection is a pattern of consumer behavior in the purchase process. Omar et al. (2001) in his study explained that a high 
impulse buying tendency can trigger pressure on impulse buying behavior. Saad and Metawie (2015) stated that a higher level of impulse buying tendency can cause a high level of urge to buy impulse buying.

\section{CONCLUSION AND SUGGESTIONS}

Store environment has a positive and significant effect on urge to buy impulsively. This means that the better the store environment applied by Mal Bali Galeria, the higher the urge to buy impulsively arising from consumers to shop for fashion products.

Impulse buying tendency has a positive and significant effect on urge to buy impulsively. This means that the higher impulse buying tendency consumers, the higher the urge to buy impulsively arising from consumers to shop for fashion products.

Urge to buy impulsively has a positive and significant effect on impulse buying. This means that the higher the urge to buy impulsively, the higher the impulse buying that will occur in the product.

Store environment has a positive and significant effect on impulse buying. This means that the better the store environment that is implemented by Mal Bali Galeria, the higher the impulse buying that will occur to consumers who will shop for fashion products.

Impulse buying tendency has a positive and significant effect on impulse buying. This means that the higher impulse buying tendency of consumers, the higher the impulse buying will occur.

Urge to buy impulsively influential significantly mediates store environment with impulse buying. Based on the calculations in this study it was found that the role of urge to buy impulsively has a weak impact mediating the relationship between store environment variables with impulse buying, because the weak impact can be said urge variables to buy impulsively can be an intervening variable because it can theoretically weaken or strengthen relationships between variables (Sugiyono, 2013: 64). This means that the better the application of the store environment then impulse buying consumers will increase this is supported by the existence of urge to buy impulsively, so that impulse buying in fashion products will increase.

Urge to buy impulsively influential significantly mediates impulse buying tendency with impulse buying. Based on the calculations in this study it was found that the role of urge to buy impulsively has a weak impact mediating the relationship between impulse buying tendency variable and impulse buying, because the weak impact can be said to be an urge variable to buy impulsively can be an intervening variable because it can theoretically weaken or strengthen relations between variables (Sugiyono, 2013: 64). This means that the higher the tendency of consumers to shop for fashion products, then impulse buying will increase, this is supported by the urge to buy impulsively towards the need for fashion will increase.

Mal Bali Galeria can work with more companies providing other non-cash transaction services, this is based on today's consumers who want an easy and practical shopping experience, with this collaboration the mall has the convenience provided to consumers in making transactions, because some consumers who find fashion products that they like, tend to buy them even if they don't bring cash.

Mal Bali Galeria is expected to be a reference for shopping for fashion products according to the needs of consumers who always follow the trend. Fashion products that are sold must be up to date so that consumers are easily provoked to shop. The marketing division of fashion products found at Mal Bali Galeria must also research different tastes of consumers, so kinsmen are easily provoked to shop for fashion products they like.

For Mal Bali Galeria, it is best to provide a stimulus to improve consumer comfort while in the mall, this can be done by fixing the layout, coloring, room temperature, music being played, also important is the availability of various fashion products in the mall, salesperson services also need to be considered, because this can give a strong push to consumers in making decisions when buying fashion products at Mal Bali Galeria. 
Providing offers and discounts at certain times (on national holidays, as well as certain events) can cause a special pleasure for consumers, so consumers will experience impulse buying of fashion products at Mal Bali Galeria.

For further researchers, it is expected to expand the scope of research with consumers spread across various regions, both regionally and nationally with fashion products that are preferred by the wider community.

Subsequent researchers can also change the object of research, for example a company engaged in the service industry that focuses more on its service experience, and should be done on several different types of products other than clothing, comparing and knowing which products are impulse buying higher for consumers. In future research also needs to be considered to use other variables so that it can enrich the information obtained such as store atmosphere variables, and positive emotions, so as to increase the occurrence of impulse buying.

Research Limitation. This research has several limitations, namely:

- The scope of this research is only for consumers of fashion products at Mal Bali Galeria, so that the results of the research cannot be generalized to consumers of fashion products in department stores or other malls that sell fashion products, besides that the respondents used are different. For further research it will be better if the scope of the research is expanded so that it can see how the implementation of impulse buying as a whole;

- This study only discusses impulse buying by consumers who are influenced by external factors (store environment) and internal consumers (impulse buying tendency and urge to buy impulsively) at Mal Bali Galeria so that the results of this study cannot be generalized to each mall because it has an environment that is different and not every consumer has a tendency or pressure to impulse buying in fashion products;

- This research is only carried out in certain time points (cross section) while the environment changes every time (dynamically), so this research is important to be done again in the future.

\section{REFERENCES}

1. Badgaiyan A.J., and Verma A. 2015. Does Urge to Buy Differ from Impulsive Buying Behaviour? Assessing the Impact of Sittuational Factors. Jurnal of Retailing and Consumer Services Vol.22, pp. 145-157.

2. Baker, J., Parasuraman, Grawel, D. \& Voss, Glenn B, 2002, The Influence of Multiple Store Environment Cues on Perceived Merchandise Value and Patronaga Intentions, Journal of Marketing, Vol.66, pp. 120-141

3. Baumeister, R. F. 2002. Yielding to temptation: self-control failure, impulsive purchasing, and consumerbehavior. Journal of Consumer Research. Vol. 28, pp. 670-676.

4. Beatty, S.E. and Ferrell, M.E. 1998. "Impulse buying: modeling its precursors", Journal of Retailing, Vol.74, No. 2, pp. 169-191.

5. Becker, L. 2000. Effect Size. Universitat Valencia. <http://web.uccs.edu/lbecker/ Psy590/es.htm>

6. Bitner, M. 1992, "Servicescapes: The Impact of Physical Surroundings on Customers and Employees," Journal of Marketing, Vol.56, No.2, pp. 57-71.

7. Chen, Tsai. 2008. Impulse Purchase Varied by Products and Marketing Channels. Journal of International Management Studies.

8. Donovan, Robert J., Rossiter, John R., Marcoolyn, Gilian., Nesdale, Andrew. 1994. Store Atmosphere And Purchasing Behaviour. Journal Of Retailing. Vol.70, No.3, pp. 283-294.

9. Dyatmika I.G.M.D.T., Sudiksa I.B. 2015. Pengaruh Promosi dan Pelayanan Ritel terhadap Pembelian Impulsif di Ramayana Mall Denpasar. E-Jurnal Manajemen Universitas Udayana. Vol. 4, No.1, pp. 21-38. 
10. Foroughi, A., Nor, A.B., Reyhane, H.M.S., 2012. Exploring the influence of situational factors (money \& time available) on impulse buying behavior among different etthics. Int. J. Fundam. Psychol. Soc. Sci. 2 (2), 41-44.

11. Foroughi, Amir., Nor Aishah Buang., Zizah Che Senik., dan Reihanehsadat Hajmisadeghi. 2013. Impulse Buying Behavior and Moderating Role of Gender among Iranian Shoppers. Journal of Basic and Applied Scientific Research. Vol. 3, No.4, pp. 760-769.

12. Gunadhi, Novy. 2012. Faktor-Faktor yang Mempengaruhi Impulse Buying Pada Carrefour di Surabaya. Fakultas Bisnis Universitas Katolik Widya Mandala Surabaya. Vol. 1, No. 4.

13. Graa, A., Dani-elKebir, M., 2012. Application of stimulus \& response model to impulse buying behavior of Algerian consumers. Serb. J. Manag. Vol.7, No. 1.

14. Hanzaee, K.H., Taherikia, F. 2010. Impulse Buying : An Iranian Model. China - USA Business Review. Vol. 9, No. 12, pp. 31-43.

15. Herawati, Arvinia., Pradhanawati, Ari., Dewi, Reni Shinta. 2013. Pengaruh Bauran Pemasaran Ritel terhadap Loyalitas Konsumen melalui Kepuasan Konsumen Pada Konsumen Alfamart di Kecamatan Tembalang Semarang. Diponogoro Journal Of Social And Politic. Vol. 2, No. 2, pp. 1-9.

16. Japarianto, Edwin dan Sugiono Sugiharto. 2011. Pengaruh Shopping Life Style dan Fashion Involvement terhadap Impulse Buying Behavior MasyarakatHigh Income Surabaya. Jurnal Manajemen Pemasaran. Vol. 6, No. 1, pp.32-41.

17. Kazempour, Y., dan Lotfizadeh, F. 2017. The Impact of Situational Factors (Store, Personal) on Urge to Buy Impulsively and Impulse Buying Behavior. European Journal of Buisness and Innovation Research.Vol. 5, No. 4, pp. 12-27.

18. Mangkunegara, Anwar Prabu. 2002. Perilaku Konsumen. Bandung : PT. Refika Aditama.

19. Mattila, A.S., Wirtz, J. 2008. The role of store environmental stimulation and social factors on impulse purchasing. J. Serv. Mark. Vol. 22, No.7, pp. 562- 567

20. Maymand, Mohammad Mahmoudi and Mostafa Ahmadinejad. 2011. Impulse Buying: The Role of Store Environmental Stimulation and Situation Factors (An Empirical Investigation). African Journal Business Management. Vol. 5, No. 34, pp. 13057 - 13065.

21. Mohan. G, Sharma. P, Sivakumaran. B. 2013. Impact of store environment on impulse buying behavior. European Journal of Marketing.

22. Muruganantham, G. and Bhakat, Ravi Shankar. 2013. A Review of Impulse Buying Behavior. International Journal of Marketing Studies. Vol. 5, No. 3, pp. $149-160$.

23. Nuzula, Firdausi dan Any Urwatul Wusko. 2014. Pengaruh Store Environment (Store environment) Terhadap Impulse Buying (Pembelian Tidak Direncana) (Studi Pada Pembeli Di Serbu Mart Sukorejo). Jurnal sketsa Bisnis. Vol. 1, No. 2

24. Omar, Ogenyi and Kent, Anthony. 2001. "International airport influences on impulsive shopping: trait and normative approach", International Journal of Retail \& Distribution Management, Vol. 29, No. 5, pp. 226-235.

25. Park, J., Lennon, S.J. 2006. Psychological and environmental antecedents of impulse buying tendency in the multichannel shopping context. J. Consum. Mark. Vol. 23, No. 2, pp. 56-66.

26. Pranata, Bayu Indra Arya. 2013. Pengaruh Website Quality terhadap Urge to Buy Impulsively pada Konsumen Online Shop di Surabaya: Peran Impulsiveness Sebagai Moderator. Undergraduate thesis, Widya Mandala Catholic University Surabaya.

27. Putra, Arya Diana dan Sukawati, Tjok Gde Raka. 2015. Peran Emotional Response Konsumen Dalam Memediasi Pengaruh Store Environment Terhadap Impulse Buying (Survei Pembeli di Carrefour Kota Denpasar). E-Jurnal Fakultas Ekonomi dan Bisnis, Universitas Udayana, Bali, Indonesia. Vol. 4, No. 1, pp. 75-91

28. Rook, D.W. 1987, "The buying impulse", Journal of Consumer Research, Vol. 14 No. 2, pp. 189-199.

29. Rook, D.W. and Fisher, R.J. 1995, "Normative influences on impulsive buying behavior", Journal of Consumer Research. Vol. 22. pp. 305-313. 
30. Saad, M., dan Metawie, M. 2015. Store Environment, Personality Factors and Impulse Buying Behaviour in Egypt: The Mediating Roles of Shop Enjoyment and Impulse Buying Tendencies. Journal of Business and Management Sciences, Vol. 3, No. 2, pp. 69-77.

31. Seetha \& J. Suganya. 2017. "A Study on Impulsive Consumer Behaviour and Its Determinants", International Journal of Current Research and Modern Education, Vol. 2, No.1, pp. 12-17.

32. Sunarto, SE.,MM. 2003. Perilaku Konsumen. Yogyakarta : Penerbit Amus Yogyakarta.

33. Susanta. 2007. Majalah Marketing/EDISI KHUSUS/II. Jakarta

34. Suprapti, Ni Wayan Sri. 2010. Perilaku Konsumen Teori Pemahaman Dasar dan Aplikasinya dalam Strategi Pemasaran. Udayana University Press.

35. Suwantari, Ni Nyoman, Ardani, I Gusti Agung Ketut Sri. 2014. Hubungan Faktor Demografi Dan Stimulus Store environment Dengan Pembelian Impulsif. E-Jurnal Fakultas Ekonomi Dan Bisnis Universitas Udayana. Vol.3, No. 4, pp. 2015 - 2034.

36. Utami, C. W. 2010. Manajemen Ritel: Strategi dan Implementasi Operasional Bisnis Ritel Moderen di Indonesia. Jakarta: Salemba Empat.

37. Verplanken, B. \& Herabadi, A. 2001. Individual Differences in Impulse Buying Tendency: Feeling and no Thinking. European Journal of Personality. Vol. 15, pp. S71-S83.

38. Xu, Yingjiao. 2007. Impact of Store Environment on Adult Generation Y Consumers' Impulse Buying. Journal of Shopping Center Research. Vol. 14, No. 1, pp. $39-56$.

39. Yistiani, Manik Ni Nyoman., Ni Nyoman Kerti Yasa., dan I. G. A Ketut Gede Suasana. 2012. Pengaruh Atmosfer Gerai dan Pelayanan Ritel Terhadap Nilai Hedonik dan Pembelian Impulsif Konsumen Matahari Department Store Duta Plaza di Denpasar. Jurnal Manajemen, Strategi Bisnis, dan Kewirausahaan. Vol. 6, No. 2, pp. 139-149.

40. Yuliartini, Ni Putu., Sulistyawati, Eka. 2014. Pengaruh Stimulus Store environment dan Faktor Lingkungan Sosial Teradap Perilaku Pembelian Impulsif Pada Carrefour Sunset Road di Denpasar. E-Jurnal Fakultas Ekonomi dan Bisnis Universitas Udayana. Vol 3, No. 4, pp. $1083-1099$.

41. Zuchdi, Darmiyati. 1995. Pembentukan Sikap. Cakrawala Pendidikan. No. 3, Thn XIV. 